\section{GOOD CORRELATION BETWEEN TWO DIFFERENT AUTOMATED FACTOR XIII ASSAYS AND PRACTICAL RECOMMENDATIONS}

\author{
Suryati Hussina, Zamzuri Idris ${ }^{b}$, Wan Zaidah Abdullaha*
}

aHaematology Department, School of Medical Sciences, Health Campus, Universiti Sains Malaysia, 16150 Kelantan, Malaysia

bNeurosurgery Department, School of Medical Sciences, Health Campus, Universiti Sains Malaysia, 16150 Kelantan, Malaysia
Article history

Received

8 April 2017

Received in revised form

22 June 2017

Accepted

10 September 2017

\section{*Corresponding author} wzaidah@usm.my

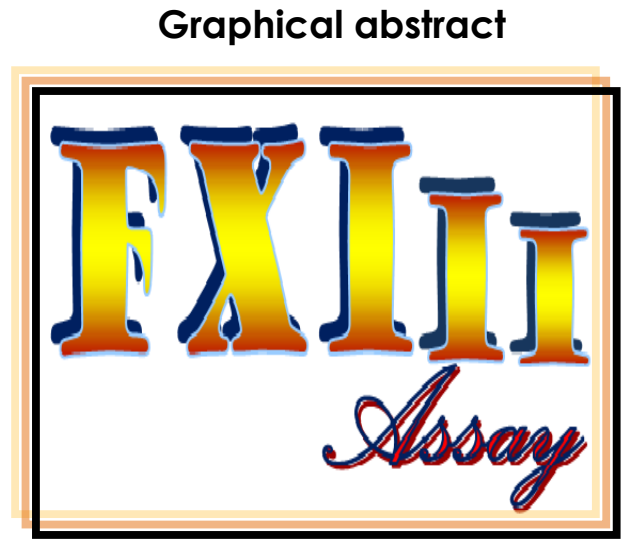

\begin{abstract}
Coagulation factor XIII (FXIII) can be quantitatively measured by using modern automated coagulation analyzers. It was uncertained whether different methods of FXIII quantitative measurement are correlated. Two different analytical methods were used for comparison in this study. This study selected a neurosurgical patient population for FXIII measurement, expecting a wide spectrum of results from haemostatic changes in vivo. A correlation study between FXIII activity (Berichrom F XIII, Dade Behring Marburg GmbH) and FXIII antigen assay (HemosILTM, Instrumentation Laboratory Company, Milano Italy) was performed using two different automated coagulation analyzers and test principles. FXIII assays using these two methods were performed on blood specimen from 84 patients taken pre and post neurosurgical procedures. A total of one hundred and thirty eight blood samples were included in this correlation study. There was a significant mean different of FXIII antigen levels pre and post intracranial surgery $(p<0.05)$. A significant, positive and good correlation between FXIII antigen and activity assays were documented by both methods, $r=0.86$, and $p<0.001$. FXIII antigens are correlated with FXIII activity assays indicating the reliability and robustness of both methods for quantitation of FXIII in the blood. These two methods are recommended for both diagnostic and research purposes.
\end{abstract}

Keywords: Factor XIII activity, factor XIII antigen assay, haemostasis neurosurgery and automated coagulation analyzer

\begin{abstract}
Abstrak
Faktor koagulasi XIII (FXIII) boleh diukur secara kuantitatif menggunakan mesin koagulasi automatik. Adalah tidak dapat dipastikan samada perbezaan kaedah pengukuran kuantitatif untuk FXIII mempunyai perkaitan. Dua metod analitikal telah digunakan di dalam kajian ini. Pesakit-pesakit neurosurgeri telah dipilih memandangkan spektrum keputusan ujian yang luas boleh diperolehi akibat perubahan hemostasis dalaman pada pedakit-pesakit ini. Kajian korelasi di antara aktiviti FXIII (Berichrom F XIII, Dade Behring Marburg GmbH) dan antigen FXIII (HemosILTM, Instrumentation Laboratory Company, Milano Italy) telah dijalankan menggunakan dua mesin koagulasi dengan prinsip ujian yang berbeza. Ujian dijalankan ke atas darah 84 pesakit sebelum dan selepas menjalani prosedur neurosurgeri. Sebanyak seratus tiga puluh lapan sampel darah telah dipilih untuk menjalani kajian ini. Terdapat perbezaan min yang signifikan di antara sampel darah sebelum dan selepas menjalani prosedur neurosurgeri $(p<0.05)$. Penemuan kajian ini mendapati korelasi positif yang baik di antara kedua metod yang digunakan untuk mengukur aktiviti dan antigen FXIII, $r=0.86$, dan $p<0.001$. Terdapat korelasi keputusan asei FXIII di antara
\end{abstract}


antigen dan aktiviti faktor ini di kalangan pesakit yang mempunyai paras F XIII yang rendah. Ini sekali gus menunjukkan kedua-dua metod boleh dipercayai tepat dan sesuai dalam pengukuran FXIII di dalam darah. Kedua metod ini dicadangkan untuk aplikasi bagi tujuan-tujuan pendiagnosan dan penyelidikan.

Kata kunci: Aktiviti faktor XIII, antigen asei faktor XIII, hemostasis, neurosurgeri dan mesin koagulasi automatik

(C) 2017 Penerbit UTM Press. All rights reserved

\subsection{INTRODUCTION}

In practice, only routine coagulation tests are performed for assessment of haemostatic function. This routine coagulation screening tests however could not detect abnormality related to coagulation FXIII. F XIII is of physiological importance in haemostasis. Congenital deficiency of FXIII is considered as a rare type of coagulation bleeding disorder [1]. However reduction or deficiency of this factor has been associated with clinical morbidities particularly related to operative procedures. A risk of postoperative haematoma in neurosurgical patients with postoperative FXIII activity under $60 \%$ was reported [2]. Another study found low FXIII activity was associated with valproate treatment and bleeding manifestation [3].

During surgical procedure, when coagulation factor deficiency is suspected (including FXIII), thromboelastography (TEG) test can be done but it is not specific to FXIII and only helped to manage blood transfusion therapy including in congenital FXIII deficiency [4]. Blood transfusion management for low FXIII includes fresh frozen plasma and cryoprecipitate [5]. TEG has been investigated for screening of FXIII deficiency. Interestingly this is a point of care instrument which is useful for bedside diagnosis especially when dealing with neurosurgical cases. However definitive diagnosis of low FXIII levels still depends on the quantitative assay [6].

FXIII catalyses the enzymatic cross-linking of fibrin monomers and forms a stable structure which protects the blood clot from premature destruction of fibrinolytic process. Coagulation FXIII consists of Asubunit (FXIII-A) and B subunit (FXIII-B). The FXIII-A contains the catalytic domain while the FXIII-B serves as a carrier protein and it circulates in plasma as a tetramer. FXIII is essential for maintaining hemostasis due to its role in fibrin stabilization [7]. FXIII is also known to be involved in wound healing [8].

FXIII circulates in plasma as a heterodimer with two catalytic FXIII-A and two carrier FXIII-B, with different sites of production: bone marrow megakaryocytes and monocyte/macrophage cell lines for FXIII-A and liver for FXIII-B. Upon thrombin cleavage, FXIII-B dissociates from FXIII-A and becomes activated. FXIII-A has a transglutaminase action that produces a gamma glutamyl epsilon lysine crosslinking between fibrin fibers, stabilizing and permitting viscoelastic resistance to shear forces and also confer resistance to fibrinolysis by plasmin. Mutations in the FXIII-A subunit have been identified and this rare type of congenital bleeding disorder requires a specific assay in the investigation, usually performed by the specialised haemostasis laboratory [9, 10, 11].

Most congenital FXIII deficiencies are a result of FXIII-A deficiency, and the FXIII-A is absent from plasma, platelets, and monocytes. On the other hand, congenital deficiency in the FXIII-B is a relatively rare cause of FXIII deficiency, and levels of the FXIII-B are usually reduced, and very rarely both FXIII-A and FXIII-B are absent. Bleeding symptoms in patients with FXIII-B deficiencies are reported to be milder than FXIII-A deficiencies $[12,13,14]$.

The classification of FXIII deficiency has been described and understanding the types could guide the necessary tests for the diagnosis of this rare bleeding disorder [15]. Diagnosis and classification of FXIII deficiencies have been based on acquired or congenital forms $[1,16]$.

Laboratory tests which are relevant to FXIII confined to blood coagulation related studies [17]. The Urea method (clot solubility qualitative assay) for FXIII screening test uses a crude procedure and insensitive to FXIII level above 5\% [18]. In order to measure the FXIII level, quantitative assay will give a definitive result as measured by automated analyzer [19].

Various methods are available for quantitative assays but correlation between different methods is not clear. The quantitative test for FXIII is basically detects antigen and activity of this factor. Guide to the interpretation of these tests is required, especially in understanding the appropriate type for patients' diagnosis. The external quality programme has been developed for the inter-laboratory comparison of this factor for the performance assessment and commonly subscribed by haemostatic laboratories [18].

The application of automated test gains a wider acceptance among users nowadays as the advantages overcome some of the other immunoassay techniques. The automated technology is more user-friendly for the operators, reproducible and gives faster results. 
In this study both types of tests (FXIII antigen and FXIII activity) used different principles and will be discussed in the methodology section below. Only FXIII-A was tested using the antigen method considering the rarity of FXIII-B deficiency and the selection of patient population from neurosurgical cases, ie involving acquired deficiency state versus the congenital deficiency.

Newer technology has been developed for FXIII measurement, however the evaluation studies between the methods are scarce. Moreover, it is unknown whether different methods of FXIII quantitative measurement are correlated. Therefore, this study aimed to correlate two different automated tests for FXIII ie antigen and activity assays. The findings hopefully could guide the haemostasis laboratory on the performance of FXIII quantitation by different test principles in non-congenital disorder in addition to the existing purpose applied for congenitally low FXIII in a patient population with bleeding disorder.

\subsection{METHODOLOGY}

A study was carried out at Hospital Universiti Sains Malaysia (USM), Kubang Kerian, Kelantan, Malaysia. Informed consent was taken from all the patients. This study was approved by the Ethical Committee for clinical study, USM.

Subjects selection:

1. Adult neurosurgical patients with the age ranged from 15 to 79 years old (mean 45.2 years old) who required intracranial surgery were recruited during this study.

2. No limitation for the types of surgical procedures.

These criteria were set mainly from the previous study which documented decreased levels of FXIII among neurosurgical patients [2].

\subsection{Sample Collection}

Blood samples for routine coagulation screening tests were drawn from the patients twice, pre-operatively and within 24 hours postoperatively with minimum trauma or stasis over the venipuncture site. Blood samples were collected into $0.106 \mathrm{mM}$ sodium citrate containers (nine parts blood to one part trisodium citrate). The left over samples from the routine tests were transferred immediately for further processing. Platelet poor plasma was obtained by a 10-minute centrifugation at 3300 r.p.m for 10 minutes. After plasma separation, the aliquots plasma were separated into cryovial containers and stored at $70^{\circ} \mathrm{C}$. Plasma samples required for factor XIII analysis were thawed at $37^{\circ} \mathrm{C}$ for 10 minutes. The analysis was performed within three hours of thawing.

\subsection{Methods}

A total of 138 from 84 patients' samples pre and post neurosurgical procedures were analysed for FXIII antigen assay using the method described below (a). Similar samples were tested for FXIII activity assay using the method described in (b). The tests were done once for each method and from the pre and postsurgical patient samples.

\section{a. FXIII antigen quantification}

FXIII antigen is quantitatively determined by automated latex enhanced immunoassay (HemosILTM) using ACL Advance analyzer (manufactured by Instrumentation Laboratory, Italy). The FXIII Ag latex reagent (Instrumentation Laboratory, Italy) used a suspension of uniform size polystyrene latex particle coated with rabbit polyclonal antibodies, highly specific for the FXIII-A. When plasma containing the active FXIII-A is mixed with the Latex Reagent and the buffer, the coated latex particles agglutinate. The degree of agglutination is directly proportional to the concentration of FXIII antigen in the sample and is determined by measuring the decrease of transmitted light caused by the aggregates. The assay was done according to the manufacturer's instructions (HemosIL ${ }^{\mathrm{TM}}$ product insert).

b. FXIII activity.

Measurement was run by Sysmex Coagulation Analyzer, CS 2000i (Sysmex Corporation, Japan) using Berichrom*FXIII reagent (Dade Behring, Marburg, Germany). FXIII contained in the sample is converted by the action of thrombin into FXIlla. Fibrin formed by the thrombin also accelerates this reaction. FXIII cross-links a specific peptide substrate to glycine ethyl ester, thereby releasing ammonia. The ammonia released is then determined in a parallel enzymatic reaction. The decrease in $\mathrm{NADH}$ is measured by monitoring the absorbance at $340 \mathrm{~nm}$. The assay was done according to the manufacturer's instructions (Berichrom*FXIII product insert).

Both FXIII antigen and activity assays were both reported in \%. Paired t-test was used to compare the means of pre and postoperative samples. Pearson Correlation test was used to determine the correlation between the two methods.

\subsection{RESULTS AND DISCUSSION}

Eighty four patients were included in this study. The mean (SD) of factor XIII antigen (\%) preoperatively and postoperatively were 72.77 (23.77) and 58.95(21.21) respectively ( $\mathrm{p}$ value < 0.001 ). However, only 138 blood samples were analyzed by both FXIII antigen and activity methods. This is due to inadequate sample collections during the study period. Among the 
84 patients studied, not all of them have both preoperative and postoperative samples.

There was a significant, positive and good correlation for factor XIII assay, $r=0.86$, and $p<0.001$. Figure 1 showed the correlation between factor XIII antigen and activity assays.

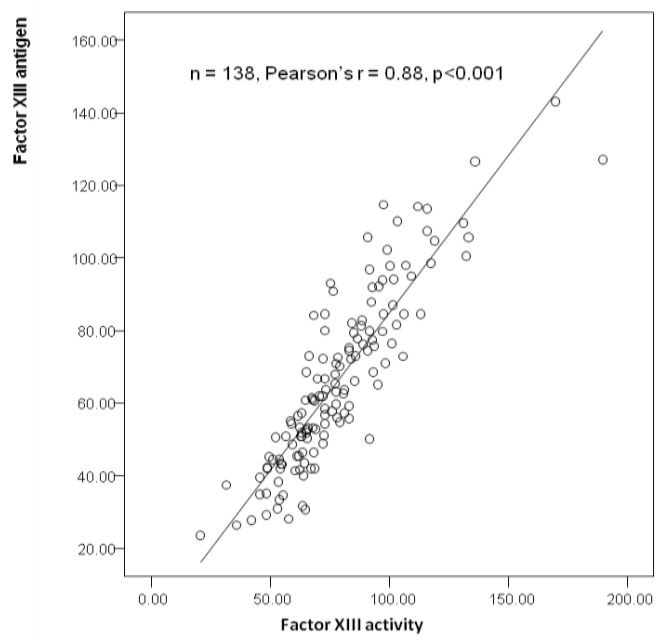

Figure 1 Correlation between factor XIII antigen and activity assay

A good correlation between FXIII antigen and activity assays has been demonstrated in this study. There was a significant decreased in FXIII antigen after the cranial surgery. This finding indicates acquired reduction of FXIII levels, most likely related to the surgical procedure and increased haemostatic activity during surgery leading to the reduction in the FXIII levels [20]. The spectrum of FXIII levels pre and post-surgery from various neurosurgical procedures allowed a wide range of FXIII levels to be tested in this correlation study.

It is important to perform FXIII assay according to the standard quality procedure. This will ensure the reliability of the test results which consider the holistic of pre-analytical, analytical and post-analytical factors. Quantitative FXIII antigen and activity assays are two different tests detecting two different aspects of FXIII. FXIII activity could reflect the amount of antigen and so far no discrepancy of antigen and activity has been reported in factor XIII disorders, unlike the other haemostatic factors such as von Willebrand factor, protein C, antithrombin and etc. Regarding these haemostatic disorders, type 1 and type 2 signify quantitative and qualitative abnormalities respectively. These aforementioned factors have two different pathological states (ie quantitative and qualitative) requiring two separate set of tests for antigen and activity measurements for diagnosis [21]. Based on this fact, choosing one method would be appropriate to quantitate plasma FXIII in medical laboratory.

FXIII measurement is reported in \% of normality. The laboratory normal reference ranges should be estimated and validated according to the selected method used. During this study, our laboratory had established local normal reference range of FXIII antigen from a group of 28 individuals, ranged from $60-116 \%$. It is therefore reasonable to test antigen of FXIII-A when deficiency is suspected by reduced FXIII activity assay in order to confirm FXIII-A deficiency. Performing both tests simultaneously may not be necessary. Another second line test can be performed if required in the event when FXIII-B deficiency is suspected, ie FXIII-A is normal and low FXIII activity is detected. The reagent should include FXIII-B testing, for example by using immunoassay method.

The role of FXIII in stabilizing blood brain barrier $(B B B)$ as mentioned by one literature may contribute to the bleeding complication, as disruption of BBB can occur during surgery or postsurgical events [22]. Low FXIII in concert with low platelet count will further compromise the haemostatic system and increase the risk of postoperative haematoma in neurosurgical patients [2, 23]. One study on chronic subdural haematoma had shown the relationship of low FXIII in contributing towards occurrence and recurrence of this complication [24]. They found $68.5 \%$ cut off value of FXIII predicts the recurrent event of SDH. The transfusion of FXIII was suggested in the management of these patients with low FXIII levels. Another study reported that FXIII administration reduces postoperative blood loss in coronary surgery with extracorporeal circulation [25].

Quantitative assessment of FXIII is available in both activity and antigen assays. In this study a significant good correlation has been documented between the two methods although they are not identical. Another study reported a similar finding [26]. In contrast to our study, their study chose normal subjects which are expected to have normal results. Our study used neurosurgical patients and therefore expected to have a spectrum of FXIII levels from normal to low values [26].

It is important to incorporate quality control measures to ensure the reliability of the test, similarly other quality activities should be practiced in parallel. Recently one study has assessed the performance of ammonia release assay which was used in one of the methods in this study. They have concluded automatic procedure seemed to decrease FXIII activity overestimation and, especially for low activity range samples $(<20 \%)$. To improve the agreement between FXIII activity and concentration, they suggested that iodoacetamide correction allows the detection of severe FXIII deficiencies (activity <5\%). Their study used plasma samples of patients with clinical symptoms suggestive of a bleeding diathesis where 20 samples showed FXIII activity less than $20 \%$ [27][28]. We did not perform this method because the report on this study recommendation was not available during the time this study was conducted. In addition, our subjects had higher levels of FXIII as compared to their subjects. In future, this method should be considered as it is easily automated with good reproducibility and more sensitive to detect low level of FXIII. In addition, the 
latest recommendation of FXIII measurement should be practiced to avoid assay limitation especially for very low FXIII levels [21].

Our study confirms the quantitation of FXIII is robust by both methods using different patient population with higher baseline FXIII levels in neurosurgical cases (compared to congenitally low FXIII).

\subsection{CONCLUSION}

In conclusion, FXIII antigen (FXIII-A) and activity measurement by different automated assays showed a good correlation in this study. FXIII might be an important factor in surgical haemostasis, in particular neurosurgical patients. It is suggested that the laboratory consider either one of these two automated assays in the quantitative measurement of FXIII for various clinical and research applications including for the diagnosis of congenital FXIII deficiency.

\section{Acknowledgement}

The authors express gratitude to the Universiti Sains Malaysia Short Term Grant 304/PPSP/6131601 for supporting this study. All authors have read the journal's policy on conflicts of interest and have none to declare.

\section{References}

[1] Kohler, H. P., Ichinose, A., Seitz, R., Ariens, R. A. and Muszbek, L. 2011. Diagnosis and Classification of Factor XIII Deficiencies. J Thromb Haemost. 9(7): 1404-1406. doi: 10.1111/j.1538-7836.2011.04315.x.

[2] Gerlach, R., Tölle, F., Raabe, A., Zimmermann, M. Siegemund, A. and Seifert, V. 2002. Increased Risk for Postoperative Haemorrhage After Intracranial Surgery in Patients with Decreased Factor XIII Activity: Implications of a Prospective Study. Stroke. 33: 1618-23.

[3] Teich, M., Longin, E., Dempfle, C. E. and König, S. 2004. Factor XIII Deficiency Associated with Valproate Treatment. Epilepsia. 45(2): 187-89.

[4] Inbal, A., Oldenburg, J., Carcao, M., Rosholm, A., Tehranchi, R. and Nugent, D. 2012. Recombinant Factor XIII: A Safe and Novel Treatment for Congenital Factor XIII Deficiency. Blood. 119(22): 5111-5117.

[5] Naderi, M., Dorgalaleh, A., Tabibian, S., Alizadeh, S., Eshghi, P. and Solaimani, G. 2013. Current Understanding in Diagnosis and Management of Factor XIII Deficiency. Iranian Journal of Pediatric Hematology and Oncology. 3(4): 164.

[6] Martinuzzo, M., Barrera, L., Altuna, D., Baña, F. T., Bieti, J., Amigo, Q., D'Adamo, M., López, M., Oyhamburu, J. and Otaso, J. 2016. Effects of Factor xiii Deficiency on Thromboelastography. Thromboelastography with Calcium and Streptokinase Addition is More Sensitive than Solubility Tests. Mediterranean Journal of Hematology and Infectious Diseases. 8(1).

[7] Muszbek, L., Adány, R. and Mikkola, H. 1996. Novel Aspects of Blood Coagulation Factor XIII. I. Structure, Distribution,
Activation, and Function. Crit Rev Clin Lab Sci. 33(5): 357421.

[8] Shi, D. Y., and Wang, S. J. 2017. Advances of Coagulation Factor XIII. Chin Med J (Engl). 130(2): 219-223. doi: 10.4103/0366-6999.198007.

[9] Tahlan, A. and Ahluwalia, J. 2014. Factor XIII: Congenital Deficiency Factor XIII, Acquired Deficiency, Factor XIII Asubunit, and Factor XIII B-subunit. Arch Pathol Lab Med. 138(2): 278-81. doi: 10.5858/arpa.2012-0639-RS.

[10] Peyvandi, F., Palla, R., Menegatti, M., Siboni, S. M., Halimeh S., Faeser, B., Pergantou, H., Platokouki, H., Giangrande, P., Peerlinck, K., Celkan, T., Ozdemir, N., Bidlingmaier, C., Ingerslev, J., Giansily-Blaizot, M., Schved, J. F., Gilmore, R., Gadisseur, A., Benedik-Dolnicar, M., Kitanovski, L., Mikovic, D., Musallam, K. M. and Rosendaal, F. R. 2012. Coagulation Factor Activity and Clinical Bleeding Severity in Rare Bleeding Disorders: Results from the European Network of Rare Bleeding Disorders. [Multicenter Study Research Support, Non-U.S. Gov't]. J Thromb Haemost. 10(4): 615-621. doi: $10.1111 /$ j.1538-7836.2012.04653.x.

[11] Ivaskevicius, V., Biswas, A., Bevans, C., Schroeder, V., Kohler H. P., Rott, H.and Oldenburg, J. 2010. Identification of Eight Novel Coagulation Factor XIII Subunit a Mutations: Implied Consequences for Structure and Function. Haematologica. 95(6): 956-962. doi: 10.3324/haematol.2009.017210.

[12] Thomas, A., Biswas, A., Ivaskevicius, V. and Oldenburg, J. 2015. Structural and Functional Influences of Coagulation Factor XIII Subunit B Heterozygous Missense Mutants. Mol Genet Genomic Med. 3(4): 258-271. doi: 10.1002/mgg3.138.

[13] Dorgalaleh, A., Naderi, M., Hosseini, M. S., Alizadeh, S., Hosseini, S., Tabibian, S. and Eshghi, P. 2015. Factor XIII Deficiency in Iran: A Comprehensive Review of the Literature. Paper Presented at the Seminars in Thrombosis and Hemostasis.

[14] Biswas, A., Ivaskevicius, V., Thomas, A. and Oldenburg, J. 2014. Coagulation factor XIII deficiency. Diagnosis, prevalence and Management of Inherited and Acquired Forms. Hamostaseologie. 34(2): 160-166. doi: 10.5482/HAMO-13-08-0046.

[15] Schroeder, V. and Kohler, H. P. 2013. Factor XIII Deficiency: an Update. Paper Presented at the Seminars in Thrombosis and Hemostasis. 39(6): 632-41. doi: 10.1055/s-0033-1353392.

[16] Muszbek, L., Bagoly, Z., Cairo, A. and Peyvandi, F. 2011. Novel Aspects of Factor XIII Deficiency. Current Opinion in Hematology. 18(5): 366-372.

[17] Dorgalaleh, A., Tabibian, S., Shams, M., Tavasoli, B., Gheidishahran, M. and Shamsizadeh, M. 2016. Laboratory Diagnosis of Factor XIII Deficiency in Developing Countries: An Iranian Experience. Lab Med. 47(3): 220-226. doi: 10.1093/labmed/Imw021.

[18] Hsu, P., Zantek, N. D., Meijer, P., Hayward, C. P., Brody, J., Zhang, X. and Van Cott, E. M. 2014. Factor XIII Assays and Associated Problems for Laboratory Diagnosis of Factor XIII Deficiency: An Analysis of International Proficiency Testing Results. Semin Thromb Hemost. 40(2): 232-238. doi: 10.1055/s0034-1365841.

[19] Sanfelippo, M. J., Mazza, J. J. and Mercier, R. J. 2014 Symptomatic Factor XIII Deficiency with Normal Urea Solubility Test. Clin Lab. 60(12): 2099-2102.

[20] Lawrie, A., Green, L., Mackie, I., Liesner, R., Machin, S. and Peyvandi, F. 2010. Factor XIII-an Under Diagnosed Deficiency-are We Using The Right Assays? Journal of Thrombosis and Haemostasis. 8(1 1): 2478-2482.

[21] Dorgalaleh, A., Tabibian, S., Hosseini, M. S., Farshi, Y., Roshanzamir, F., Naderi, M. and Shamsizadeh, M. 2016. Diagnosis of Factor XIII Deficiency. Hematology. 21 (7): 430439.

[22] Noll, T., Wozniak, G., Mohammad, A. and Piper, H. M. 1999. Effect of Factor XIII on Endothelial Barrier Function. J Exp Med. 189(9): 1373-82.

[23] Idris, Z., Muzaimi, M., Hussin, S., Mahmood, W. H. and Abdullah, W. Z. 2012. Association of Perioperative Factor XIII Activity Levels and Other Haemostatic Markers with the Risk of Postoperative Intracranial Haematoma in a Selected 
Cohort Of Neurosurgical Patients. Acta Neurochir. 154(5): 887-894.

[24] Bosche, B., Molcanyi, M., Noll, T., Kochanek, M., Kraus, B., Rieger, B., El Majdoub, F., Dohmen, C., Lohr, M., Goldbrunner, R. and Brinker, G. 2013. Occurrence and Recurrence of Spontaneous Chronic Subdural Haematoma Is Associated with A Factor XIII Deficiency. Clin Neurol Neurosurg. 115(1): 13-8.

[25] Gödje, O., Gallmeier, U., Schelian, M., Grünewald, M. and Mair, H. 2006. Coagulation Factor XIII Reduces Postoperative Bleeding After Coronary Surgery with Extracorporeal Circulation. Thorac Cardiovasc Surg. 54(1): 26-33.

[26] Alhomsi, K., Salem, R. O., Morin, K. A. and Van Cott, E. M. 2007. Evaluation of a New, Automated Quantitative Factor
XIII Assay. XXIst Congress of the International Society on Thrombosis and Haemostasis. Geneva, Switzerland. July 612.

[27] Cini, M., Legnani, C., Frascaro, M., Pancani, C., Cappelli, C. Rodorigo, G., Valdrè, L, and Cosmi, B. 2016. Measurement of Factor XIII (FXIII) Activity by an Automatic Ammonia Release Assay Using lodoacetamide Blank-Procedure: No More Overestimation In The Low Activity Range And Better Detection of Severe FXIII Deficiencies. Clin Chem Lab Med. 54(5): 805-9.

[28] Jennings, I., Kitchen, S., Woods, T. and Preston, F. 2003. Problems Relating to the Laboratory Diagnosis of Factor XIII Deficiency: A UK NEQAS study. Journal of Thrombosis and Haemostasis. 1 (12): 2603-2608. 